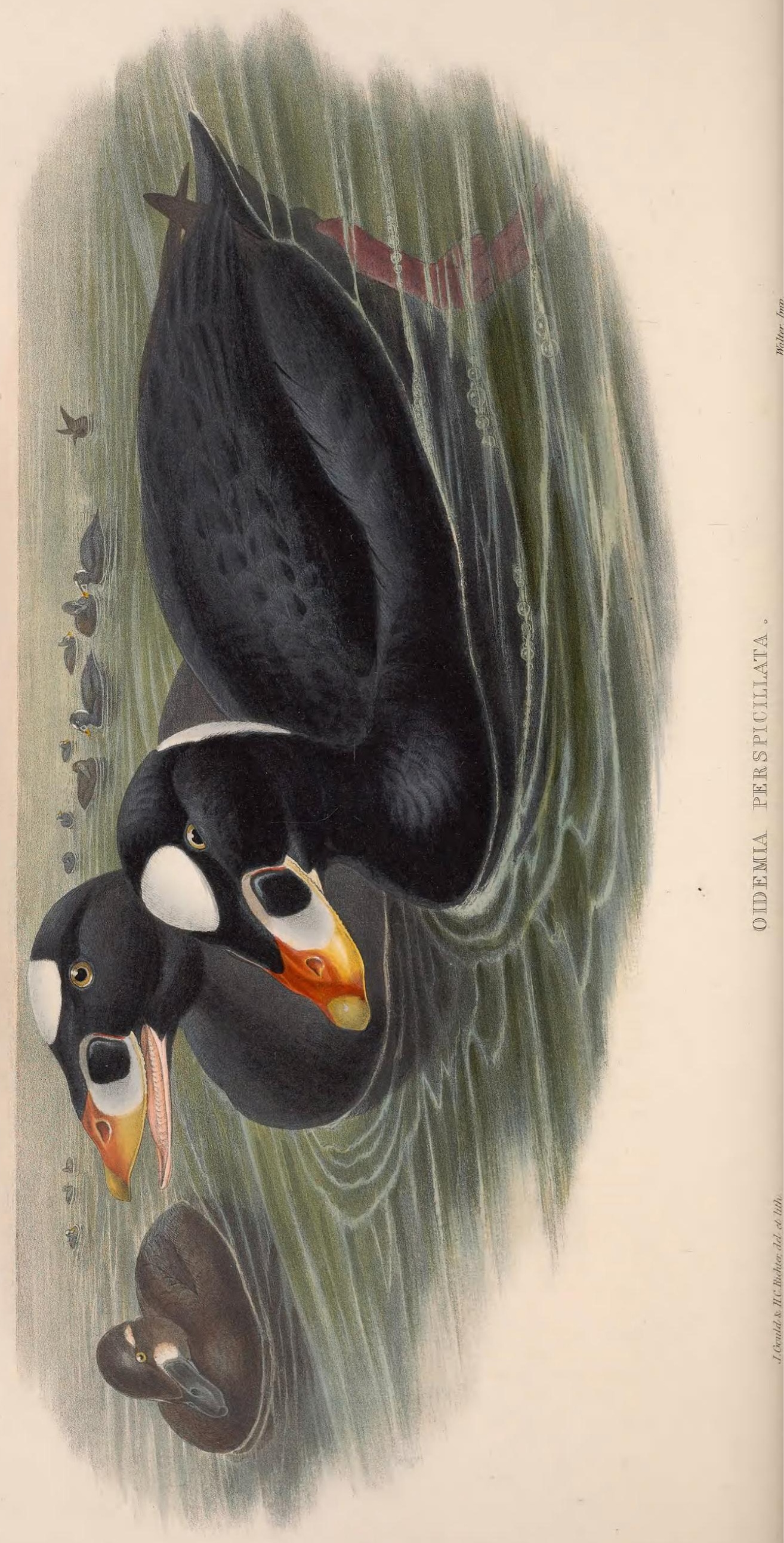




\section{OIDEMIA PERSPICILLATA.}

\section{Surf-Scoter.}

Anas perspicillata, Linn. Syst. Nat., tom. i. p. 201.

Oidemia perspicillata, Steph. Cont. of Shaw's Gen. Zool., vol. xii. p. 219.

Melanitta perspicillata, Boie, Isis, 1822, p. 564.

Fuligula perspicillata, Bonap. Syn. of Birds of United States, p. 389.

Pelionetta perspicillata, Kaup, Natürl. Syst., p. 107.

"THe sea and its living wonders!" What a vast field for the contemplation of the naturalist is embodied in those words! for how variable and extraordinary are the productions of the watery portion of our globe, and how deeply are they imbued with interest-whether we regard the forests of Fuci, which grow in its shallower portions, the extensive beds of corallines which are building up a base for some future continent, the myriads of those lower organisms shedding phosphorescent light, the Physalice, the Gasteropoda, the fishes of innumerable forms, or the gigantic whale! nor less remarkable are the numerous kinds of birds which habitually frequent its surface, the aerial Frigate-Birds, the buoyant Albatroses, the tripping Petrels, the diving Penguins, the rock-loving Puffins and Guillemots, and others, as numerous and as varied as those of the dry land. To say that animal life is feebly represented in the ocean, or that a voyage over its surface is necessarily monotonous, is untrue; for even in its midst both birds and the lower forms of life are extremely numerous, and it is well known that every part of its shores is tenanted by a vast variety of different genera and species, whose structure is as ill-adapted for the wide expanse as the Albatros is for the roaring rollers which the bird here represented loves to frequent, and whence it is called Surf-Duck or Surf-Scoter. This remarkable species may surely be included among the "sea's living wonders ;" for how extraordinary is the form of its bill and head, how brightly are they coloured, and how curiously are they marked! Those who have not had opportunities of seeing the bird in a state of nature will scarcely believe that any duck is so fantastically adorned; yet such is really the case; and fresh-killed specimens will outvie my drawing in every respect. In America this bird is very abundant along the shores of the eastern coast, from Florida to Labrador; but, being a northern species, it frequently crosses to the seas of Norway, Denmark, and Holland, and also to those of the British Islands, where it has been killed sufficiently often to entitle it to a place in our avifauna. Ornithologists are divided in their opinions as to whether the Surf-Scoter found on the uorth-western portion of America be the same as the one frequenting the eastern coasts ; if they be identical, then the bird probably ranges over all the northern shores of the globe.

For a knowledge of the habits and economy of the Surf-Scoter, we must refer to the interesting pages of the celebrated American writers Wilson and Audubon. According to the former, "this duck frequents the shores and bays of the sea, particularly where the waves roll over the sandy beach. Their food consists principally of small bivalve shell-fish, spout-fish, and others that lie in the sand near its surface. For these they dive almost constantly, both in the sandy bays and amid tumbling surf. Their skins are remarkably strong, and their flesh coarse, tasting of fish. They are common in winter along the whole coast, from the river St. Lawrence to Florida, but leave us early in May for their breeding-places in the north."

"While proceeding," says Audubon, "towards the sterile country of Labrador, in 1833, I found the waters of the Gulf of St. Lawrence alive with ducks of different species. The nearer we approached the coast, the more numerous did they become; and, of the many that presented themselves to our anxious gaze, the Surf-Duck was not the least abundant. It is true that in the noble bays of our coast, in the Sound between New York and the Hook, on the broader waters of the Chesapeake, and beyond them to the mouths of the Mississippi, I had seen thousands of Surf-Ducks ; but the numbers that passed the shores of Labrador, bound for the far north, exceeded all my previous conceptions. For more than a week after we had anchored in the lovely harbour of Little Macatina, I anxiously searched for the nest of this species in vain. At length I found that a few pairs had remained in the neighbourhood; and one morning while searching for the nests of the Red-breasted Merganser over a vast oozy and treacherous freshwater marsh of about three miles in length, two miles distant from the harbour, and fully five and a half from the waters at the Gulf of St. Lawrence, I suddenly started a Surf-Duck from her treasure. The nest was snugly placed amid the tall leaves of a bunch of grass, and raised fully four inches above its roots. It was entirely composed of withered and rotten weeds, the former being circularly arranged over the latter, producing a wellrounded cavity, six inches in diameter, by two and a half in depth. The borders of this inner cup were lined with the down of the bird, in the same manner as the Eider's nest; and in it lay five eggs, the smallest number I have ever found in any duck's nest. They were two inches and two-eighths and a half in length, by one 
inch and five-eighths in their greatest breadth, more equally rounded at both ends than usual, the shell perfectly smooth, and of a uniform pale yellowish or cream colour. I saw no male near the nest, but in the course of the same day met with several males by themselves, about four miles distant from the marsh, as I was returning to the harbour. This induced me to believe that, like the Eider and other ducks that breed in Labrador, the males abandon the females as soon as incubation commences. I regret that, notwithstanding all my further exertions, I did not succeed in discovering more nests or young birds. The Surf-Duck is a powerful swimmer and an expert diver. It is frequently observed fishing at the depth of several fathoms, and it floats buoyantly among the surf or the raging billows, where it seems as unconcerned as if it were on the most tranquil waters. It rises on wing, however, with considerable difficulty, and in this respect resembles the Velvet Duck; but when once fairly under weigh, it flies with great rapidity and to a great distance, passing close to the water during heavy gales, but at the height of forty or fifty yards in calm and pleasant weather. It is uncommonly shy, and therefore difficult to be obtained, unless shot at while flying or when asleep and, as it were, at anchor in a bay, or near the shore; for it dives so suddenly as to elude the best percussion-lock guns. The female, which was killed as she flew from the nest, uttered a rough, uncouth, guttural cry, somewhat resembling that of the Goosander on similar occasions; and I have never heard any other sound from either sex. I have never seen this bird on any freshwater lake or river in any part of the interior."

I am indebted to the kindness of Mr. H. E. Dresser for the following interestıng notes on the bird as seen by him in Nova Scotia :-

"The Surf-Scoter is not uncommon on the coast of New Brunswick during its spring migration, and in some seasons occurs in great numbers. This was the case in 1862, when I spent a few days at Lepreaux Lighthouse, which is placed on a rocky point jutting out from the mainland into the Bay of Fundy. On my arrival there on the 25th of April myriads of ducks were flying past, among which Surf-Scoters were more numerous than any other species. They followed the line of the coast at a short distance from the shore, and in passing the point generally steered close in, or flew over the end of the point itself. On the 26th I spent the day among the rocks; and I never recollect seeing waterfowl in such countless numbers as I did on that day, all wending their way northward. Velvet, Common, and especially Surf-Scoters, were the most numerous; but there were also many Eiders, Brents, Long-tailed Ducks, with a few Harlequins, Great Northern Divers, and some others. The Surf-Scoters flew in large compact flocks, from eight to ten deep. I determined the length of the flocks by watching them as they passed certain points, the distance between which was known to me; and I thus found that one compact flock was at least half a mile in length, a second reached from one point to another, distant nearly a mile and a quarter. I made several very telling shots amongst them, knocking over eight at one discharge, and six and four at a double shot, thongh I was only using a light fifteen-bore gun. I found them, however, very hard to recover; for during the time the dog was retrieving them one or two were sure to come to and paddle off, and the sea was too rough to go out in a boat to pick up the cripples. The males proved to be far more numerous than the females, of which sex I only killed three during the whole day. The flesh of the Scoter is generally considered very unpalatable; but during my stay the lighthouse-keeper's wife gave us some capital dishes composed of it. Perhaps hunger was the sauce that made it so pleasant to me; but I suspect that the manner in which they were prepared had a great deal to do with it; for I have repeatedly tried the experiment when camping on the sea-shore, but always failed in rendering it agreeable."

Professor Nilsson states, in his 'Fauna of Scandinavia,' that the Surf-Scoter is so rare in that part of the world that it had only occurred once or twice, - the first time in 1833, when the specimen from which his description and figure was taken was killed in Kazesuando, and sent to the Stockholm Museum by the Rev. L. L. Læstadius; the second was killed at Calmar on the 14th of June 1846, and was sent to the same museum by the Pilot Wirsén.

In our islands, examples have been procured on the coasts of Orkney; and the late Robert Dunn states that he saw a specimen in Rona's Voe, Shetland, in June 1847. I have myself had an example from the Frith of Forth; Mr. Bartlett had one sent to him for preservation, as mentioned in 'The Naturalist,' vol. iii. p. 420. In September 1865, Mr. Rodd, of Penzance, informed me that he had just seen a splendid male Surf-Scoter, which was captured in a disabled state by a boy at Scilly, and that a specimen in his own collection was brought to him by a man who said he had picked it up within reach of the shore. Still more recently a fine male was shot by Mr. J. H. Dunn near Stromness, at the end of March 1866 . It is now in the possession of Vauncy Harpur-Crewe, Esq.

The female differs from the male in having the entire plumage of the body dull brownish black, and in being devoid of the rich colouring of the bill, and the patches of white on the head and the back of the neck, as will be seen on reference to the reduced figure of this sex on the opposite Plate, where two males are represented of the size of life. 


\section{$2 \mathrm{BHL}$ Biodiversity Heritage Library}

Gould, John. 1873. "Surf Scoter, Oidemia perspicillata [PI. 30]." The birds of Great Britain 5, -. https://doi.org/10.5962/p.324074.

View This Item Online: https://www.biodiversitylibrary.org/item/222497

DOI: https://doi.org/10.5962/p.324074

Permalink: https://www.biodiversitylibrary.org/partpdf/324074

\section{Holding Institution}

Smithsonian Libraries

\section{Sponsored by}

Biodiversity Heritage Library

\section{Copyright \& Reuse}

Copyright Status: Public domain. The BHL considers that this work is no longer under copyright protection.

This document was created from content at the Biodiversity Heritage Library, the world's largest open access digital library for biodiversity literature and archives. Visit BHL at https://www.biodiversitylibrary.org. 